\title{
Solar drying of drying agricultural product (Apricot)
}

\author{
Foued Chabane ${ }^{1,2^{*}}$, Djamel Bensahal ${ }^{3}$, Abdelhafid Brima ${ }^{1,2}$, Noureddine Moummi ${ }^{1,2}$ \\ ${ }^{1}$ Department of Mechanical Engineering, Faculty of Technology, University of Biskra 07000, Algeria \\ ${ }^{2}$ Laboratoire de Génie Mécanique (LGM), Faculty of Technology, University of Biskra 07000, Algeria \\ ${ }^{3}$ Department of Mechanical Engineering, Faculty of Technology, University of Laghouat 03000, Algeria
}

Corresponding Author Email: fouedmeca@ hotmail.fr

https://doi.org/10.18280/mmep.060112

Received: 27 October 2018

Accepted: 2 March 2019

Keywords:

drying room, solar air collector, moisture content, mass flow rate, apricot, temperature

\begin{abstract}
This work allowed us to study the effects of some parameters on drying and specify the most influential. Drying is basically a phenomenon of removal of liquid by evaporation from an apricot. Solar drying is one of the processes that have found application in Algeria, because of the important quantities of solar irradiations that can be exploited in this country.Drying basically comprises of two fundamental and simultaneous processes: heat is transferred to evaporate liquid, and mass is transferred as a liquid or vapor within and the apricot as a vapor from the surface. The experimental study is investigated in the Biskra city of Algeria for drying Apricot in the drying room which it integrated with a solar air collector (new design) which the drying chamber receives the temperature from the solar collector which absorbed from sun. We have to spread the produce on a suitable surface and let it dry in the drying room and added the study of thermal performance of solar air collector and trying with three different airflow rates, namely, $0.018,0.028$ and $0.034 \mathrm{~kg} / \mathrm{s}$ are conducted. Finally the results have been illustrated with mass water content, product temperature, drying room temperature, outlet temperature in both solar collector and drying room and enthalpy of solar collector and drying room which effect with increase the mass flow rate.
\end{abstract}

\section{INTRODUCTION}

The solar drying it's the process which gives the free energy of hot air used in the drying room for evaporated the water into apricot. In this study we design the both of solar collector and the drying chamber which integrate with it, which give one system of drying, we are trying to test the apricot by it and the result talk about this design realized, it is the observation study.

An improved technology in utilizing solar energy for drying agricultural is the use of solar dryers where the air is heated in a solar collector and then passed through products. There are two basic types of solar dryer appropriate for use with agricultural: natural convection dryers where the air flow is induced by thermal gradients; and forced convection dryers wherein air is forced through a solar collector. In this study the drying solar with forced convection, The forced convection solar dryer can be considered as a conventional mechanical drying system in which air is forced through a dried product holder but the air is heated by a flat plate solar collector rather than by more conventional means.

Most developing countries are unable to solve their food problems for then tire population because of the rapidly increasing number of people in their respective territories.

Some research effort to design and develop a forced convection solar dryer using evacuated tube air collector. Their performance was compared with natural sun drying. The results of the present study show that the proposed solar dryer has been greater efficiency, and the moisture content of bitter gourd is reduced from $91 \%$ to $6.25 \%$ in 6 hours as compared to 10 hours in natural sun drying [1].

Another work studies an experimental study was conducted to investigate the performance of a solely solar drying system and a system equipped with an auxiliary heater as a supplement to the solar heat, [2]. The performances of both are compared to that of natural drying. Beans and peas are dehydrated in a system that consists of two flat plate collectors, a blower, and a drying chamber. Tests with four different airflow rates, namely, $0.0383,0.05104,0.0638$, and $0.07655 \mathrm{~m}^{3} / \mathrm{s}$ were conducted. The efficiency of the mixed drying system was found to increase by $25 \%$ to $40 \%$ compared to the solely solar drying. A best fit to the experimental data of peas and beans was obtained by six exponential equations for the various systems with a correlation coefficient in the range 0.933 and 0.997 .

Solar drying can be an effective means of food preservation since the product is completely protected during drying against rain, dust, insects and animals [3].

There is a great diversity of designs and modes of operation: forced convection, Ahmad et al., [4], Indirect forced convection, Bahlou et al., [5], Direct cabinet and indirect cabinet solar dryers, Banoult et al., [6], Solarbiomass hybrid dryer enhanced by the Co-Gen technique, Tadahmun and Hussai, [7]; Leon and Kumar, [8], Greenhouse solar dryers, Abdullah, [9]; Bechoff et al., [10], Direct solar dryer, Hii et al., [11], Heat pumps, Fadhel et al., [12]; Li et al., [13], Indirect natural convection solar dryer with chimney, solar dryer with greenhouse as collector, solar tunnel dryer (air collector), hybrid solar dryer assisted by 
evacuated tube collectors, Jairaj et al., [14]. F. Chabane \& al [15-26], Presents a study of heat transfer in a solar air heater by using new design of solar collector. The collector efficiency in a single pass of solar air heater without, and with using fins attached under the absorbing plate has been investigated experimentally the maximum efficiency obtained for the 0.012 and $0.016 \mathrm{~kg} / \mathrm{s}$ with, and without fins were $40.02,51.50 \%$ and $34.92,43.94 \%$.

\section{CHARACTERISTICS OF WET SOLIDS}

The water-film solid adheres to its external surface by surface forces. A boundary layer at the periphery of the solid is constituted by air saturated with water, that is to say air containing water. Water vapor at a partial pressure equal to the vapor pressure of water that would be present in a chamber at the same temperature.

Let a mass $\mathrm{Mh}$ of wet material containing a mass Me of water and a mass Ms of dry matter:

$\mathrm{M}_{\mathrm{h}}=\mathrm{M}_{\mathrm{e}}+\mathrm{M}_{\mathrm{s}}$

\subsection{Absolute humidity}

Authoritarian humidity or moisture content or content (Kgav / Kgas) in dry-based water, where more simply moisture is expressed by liquid contained in the product in relation to its dry mass.

$$
X=\frac{M_{e}}{M_{s}}=\frac{M_{h}-M_{s}}{M_{s}}
$$

\subsection{Moisture-based water content}

Relative humidity where water content $(\%)$, or moisturebased water content is expressed by the mass of liquid contained in the product relative to its wet mass.

$$
X_{r}=\frac{M_{e}}{M_{e}+M_{s}}
$$

\subsection{Drying speed}

The drying rate is the mass of evaporated water per unit of time and per unit area of evaporation of the material. The expression of the drying speed is then written:

$$
\begin{aligned}
& R=-\frac{d M_{v}}{s \cdot d t}=\frac{M_{s} \cdot d x}{s \cdot d t} \\
& M_{v}=M_{s} \cdot d x \\
& d x=X_{e}-X_{s}
\end{aligned}
$$

\section{EXPERIMENTAL STUDY}

In this study, we focused on agro-food drying, using a solar collector and a drying chamber, which we manually performed in the technological hall of the Department of
Mechanical Engineering of the University of Biskra, carried out in the period from February to May 2018.

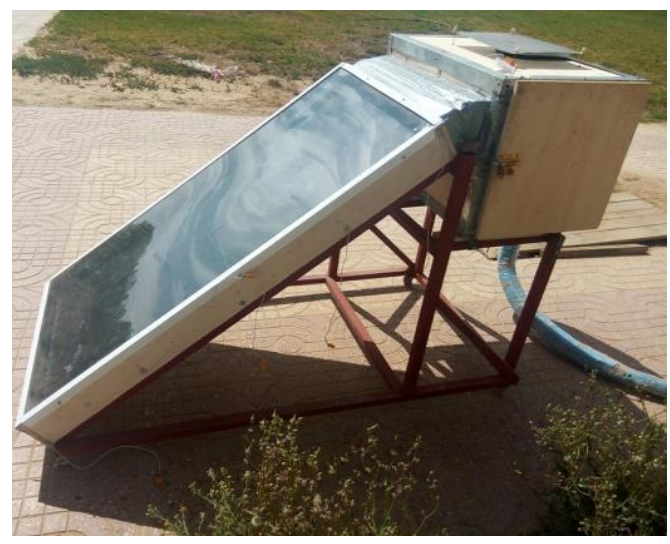

Figure 1. Experimental setup (solar collector with drying chamber)

\subsection{Description of the test bench}

The experiment bench tests were carried out near the technological hall of the Department of mechanical engineering of the University of Biskra, which is located at the south-east of the Algerian Sahara at $34.5042^{\circ}$ of latitude, at $5.4447^{\circ}$ of longitude and at 105 meters of altitude. The experiment site is exposed to the sun.

In our case for the realization of the sensor we had recourse to the design of the following elements:

a. The box: is in the shape of wooden box of multiple type of thickness $15 \mathrm{~mm}$ which will be used as base for the sensor, its dimensions are $153 \mathrm{~cm} \times 83 \mathrm{~cm} \times 10 \mathrm{~cm}$.

We placed holes $20 \mathrm{~mm}$ in diameter along the upper and lower front of the box to enter and exit the air. As can be seen Figure 2 .

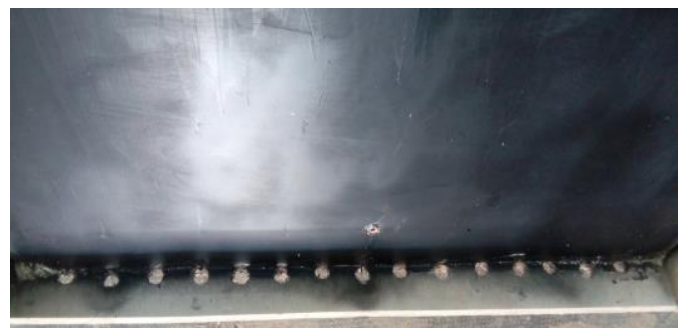

Figure 2. Holes of inlet solar collector

b. Insulation: Thermal insulation refers to all the techniques used to limit heat transfer between a hot environment and a cold environment, for this we used a good type of polystyrene with dimensions of $147 \mathrm{~cm} \mathrm{x} 77 \mathrm{~cm} \mathrm{x} 4 \mathrm{~cm}$.

c. Characteristic of polystyrene:

- The thickness of the polystyrene is $4 \mathrm{~mm}$, which makes it solid and of high quality.

- It retains the temperature for a long time.

- It supports a temperature up to $100^{\circ} \mathrm{C}$.

- It is flammable, with a self-ignition temperature of about $490^{\circ} \mathrm{C}$.

d.Reflective Film: is a plywood type pad that separates the insulation from the absorber, to avoid affecting the insulation of sunlight concentrated in the absorber, its dimensions are $150 \mathrm{~cm} \times 80 \mathrm{~cm}$.

e. Characteristic of plywood: 
- Good flexural strength and modulus of elasticity.

- Resist moisture.

- Resistant to high temperatures

f. The absorber: The solar absorber is the part of the solar heating system that captures the heat and transmits it to the air (for solar air heating). It acts as a heat exchanger that turns solar energy into heat. We made it in galvanized sheet with the same dimensions as the reflective film.

g. Glazing (Plexiglas): is a material with multiple applications. This thermoplastic, which can be molded by compression, injection, casting, blowing and extrusion, comes in many colors and in many forms (panels, blocks, pipes, bars). Feature of Plexiglas:

- This very clear material with a glossy appearance has a very high transparency and a higher light transmission than glass (its optical index is 1.49).

- It is resistant to UV rays, corrosion and atmospheric agents while being much lighter than glass $\left(1.19 \mathrm{~g} / \mathrm{cm}^{3}\right.$ density).

- Finally, it's very smooth and shiny surface appearance makes it an aesthetic material, even design, that can be used in the fields of construction and furnishing.

\subsection{Manufacture of the drying chamber}

The room is made of multiple type wood, protected on all sides with good quality insulation. Connect to the solar panel by a pipe, which passes air through holes to distribute this air on the dried product; its dimensions are $80 \mathrm{~cm} \times 50 \mathrm{~cm} \times 50 \mathrm{~cm}$.

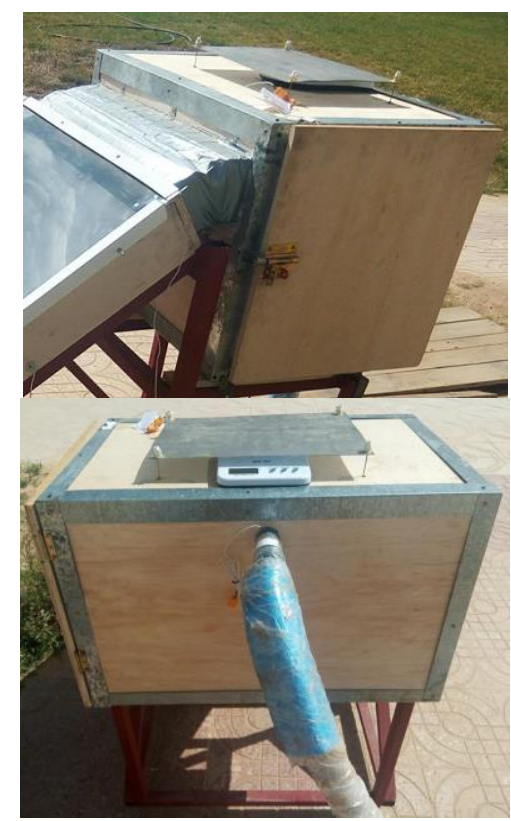

Figure 3. Experimental setup of drying chamber

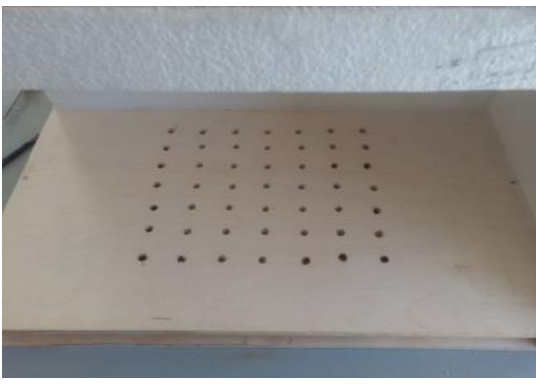

Figure 4. Orifices into drying chamber

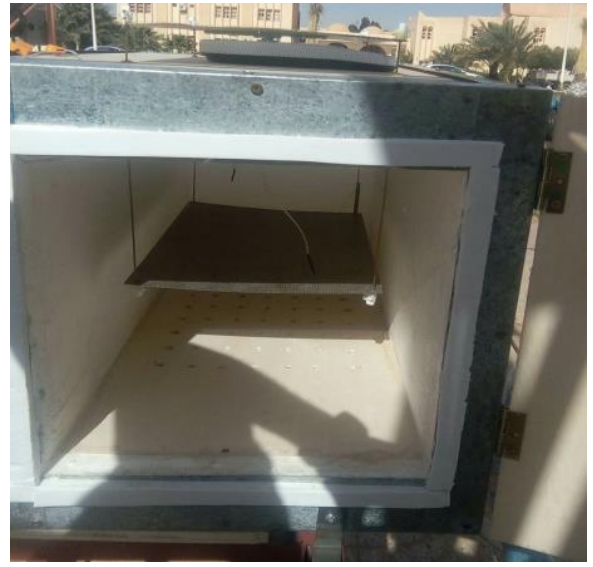

Figure 5. Support of the product

-Orifices: We drilled holes in order to distribute the air on the product and avoid burning it. In our case, we put holes 10 $\mathrm{mm}$ in diameter in a square board, $30 \mathrm{~cm}$ by $30 \mathrm{~cm}$. As show in Figure (4).

-The grate: Is a support on which the product is arranged, with holes for the removal of water, attached by four rods equilibrated to allow us to weigh the product without removing it (see Figure 5, This grid is characterized by its hardness and resistance to rust.

\subsection{Flow measurement}

To measure the flow, we used (the vacuum cleaner see Figure 6, the anemometer and the voltage regulator), to have a link between the voltage and the speed see Tab.1. Use of the debit law:

$m=\rho . V . S$

Table 1. Adjusting the flow in terms of voltage

\begin{tabular}{|c|c|c|c|}
\hline $\begin{array}{l}\text { Voltage } \\
\text { (Volt) }\end{array}$ & $\begin{array}{c}\text { Speed } \\
(\mathrm{m} / \mathrm{s})\end{array}$ & $\begin{array}{c}\text { Surface } \\
\left(\mathbf{m}^{2}\right)\end{array}$ & $\begin{array}{c}\text { Mass flow rate } \\
(\mathrm{kg} / \mathrm{s})\end{array}$ \\
\hline 50 & 0.72 & \multirow{7}{*}{0.00785} & 0.0067824 \\
\hline 56 & 1.12 & & 0.0105504 \\
\hline 60 & 2 & & 0.01884 \\
\hline 62 & 2.63 & & 0.0247746 \\
\hline 64 & 3.1 & & 0.029202 \\
\hline 68 & 3.5 & & 0.03297 \\
\hline 70 & 3.7 & & 0.034854 \\
\hline
\end{tabular}

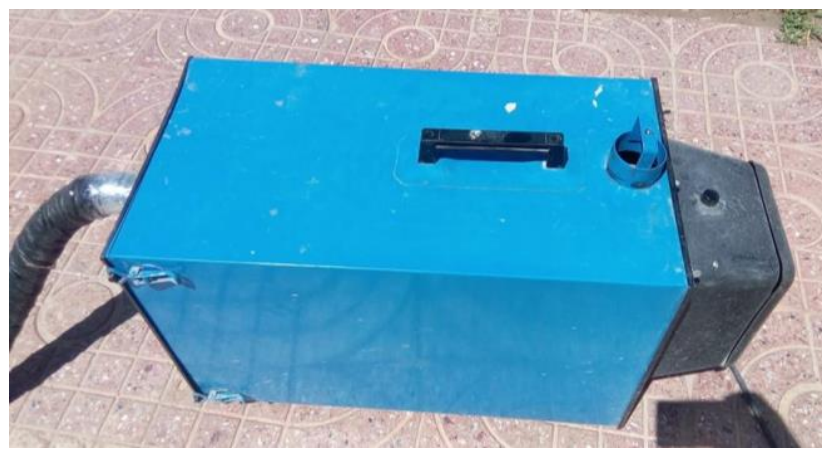

Figure 6. Vacuum cleaner for air circulation control

\section{-Preparation for the test:}

-Experimental determination:

The dimensions of the collector are: 
Dimensions (general): $1.53 \mathrm{~m} \mathrm{x} 0.83 \mathrm{~m}$.

- $\quad$ Dimensions (specific): $1.50 \mathrm{~m}$ x $0.80 \mathrm{~m}$.

Calculation of the collector surface:

- $\quad$ Total area: 1.27

- $\quad$ Area (specific): 1.20

- Dimensions of the drying chamber:

- $\quad$ Dimensions (general): $0.80 \mathrm{~m} \times 0.50 \mathrm{~m} \times 0.50$

- Dimensions (specific): $0.73 \mathrm{~m} \times 0.42 \mathrm{~m} \times 0.39$

Calculation of the volume of the drying chamber:

Total volume: 0.20

Characteristics of the drying process:

We summarized the results of the drying process in the table 2 showing the state of the product before and after drying with a characteristic average, the results are as follows:

Table 2. Statistical results obtained from Apricot for different flows

\begin{tabular}{|c|c|c|}
\hline$m$ & $0.018 \mathrm{~kg} / \mathrm{s}$ & \multirow[b]{7}{*}{ Before drying } \\
\hline$G$ & $862.4 \mathrm{~W} / \mathrm{m}^{2}$ & \\
\hline$V_{\text {with }}$ & $1.36 \mathrm{~m} / \mathrm{s}$ & \\
\hline$T_{\text {ante }}$ & $27.68^{\circ} \mathrm{C}$ & \\
\hline$T_{s, \text { chares }}$ & $58.73^{\circ} \mathrm{C}$ & \\
\hline$T_{s, \text { chane }}$ & $46.43^{\circ} \mathrm{C}$ & \\
\hline$T_{p v}$ & $29.64^{\circ} \mathrm{C}$ & \\
\hline$T_{\text {cham }}$ & $42.14^{\circ} \mathrm{C}$ & \multirow{5}{*}{ After drying } \\
\hline$\Delta T_{\text {Chembots }}$ & $-12.3^{\circ} \mathrm{C}$ & \\
\hline$M_{i}$ & $424 \mathrm{~g}$ & \\
\hline$M_{a t}$ & $255 \mathrm{~g}$ & \\
\hline$M_{w}$ & $169 \mathrm{~g}$ & \\
\hline$m$ & $0.029 \mathrm{~kg} / \mathrm{s}$ & \\
\hline$G$ & $885.75 \mathrm{~W} / \mathrm{m}^{2}$ & \\
\hline$V_{\text {wind }}$ & $2.65 \mathrm{~m} / \mathrm{s}$ & \\
\hline$T_{\text {aecb }}$ & $28.76^{\circ} \mathrm{C}$ & \\
\hline$T_{d \text { chent }}$ & $53.96{ }^{\circ} \mathrm{C}$ & \\
\hline$T_{x, \text { cham }}$ & $45.40^{\circ} \mathrm{C}$ & \\
\hline$T_{p r}$ & $39.24^{\circ} \mathrm{C}$ & $g$ \\
\hline$T_{\text {eham }}$ & $43.41^{\circ} \mathrm{C}$ & \\
\hline$\Delta T_{\text {Chambire }}$ & $-8.56^{\circ} \mathrm{C}$ & \\
\hline$M_{i}$ & $370 \mathrm{~g}$ & \\
\hline$M_{\Delta r}$ & $227 \mathrm{~g}$ & \\
\hline$M_{w}$ & $143 \mathrm{~g}$ & After drying \\
\hline
\end{tabular}

\begin{tabular}{|c|c|c|}
\hline$m$ & $0.034 \mathrm{~kg} / \mathrm{s}$ & \\
\hline$G$ & $982 \mathrm{~W} / \mathrm{m}^{2}$ & \\
\hline$V_{\text {wind }}$ & $0.90 \mathrm{~m} / \mathrm{s}$ & \\
\hline$T_{\mathrm{amb}}$ & $28.05^{\circ} \mathrm{C}$ & \\
\hline$T_{d, \text { eken }}$ & $54.50^{\circ} \mathrm{C}$ & \\
\hline$T_{\text {x,chant }}$ & $45.35^{\circ} \mathrm{C}$ & Before drying \\
\hline$T_{5}$ & $33.78^{\circ} \mathrm{C}$ & \\
\hline$T_{\text {ehaes }}$ & $40.20^{\circ} \mathrm{C}$ & \\
\hline$\Delta T_{\text {Chambire }}$ & $-9.14^{\circ} \mathrm{C}$ & * \\
\hline$M_{4}$ & $450 \mathrm{~g}$ & \\
\hline$M_{\text {st }}$ & $281 \mathrm{~g}$ & \\
\hline$M_{w}$ & $169 \mathrm{~g}$ & After drying \\
\hline
\end{tabular}

\section{RESULTS AND DISCUSSION}

Figure 7 show the variation of moisture content as a function to total time in minutes according to mass flow rate. We remark that variation its observation in the beginning operation to $200 \mathrm{~min}$ and then the curves it's approaching together to when the dry is stable. The dry product of Acripot doesn't depend of the total mass but relate of the time and the speed dry.

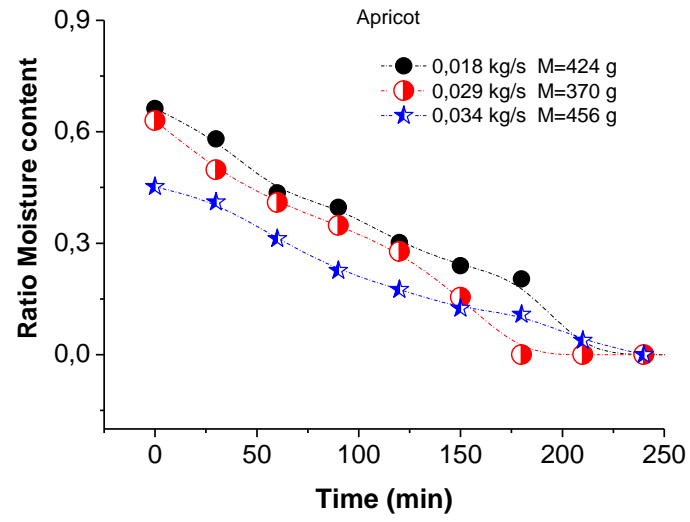

Figure 7. Moisture content of Apricot

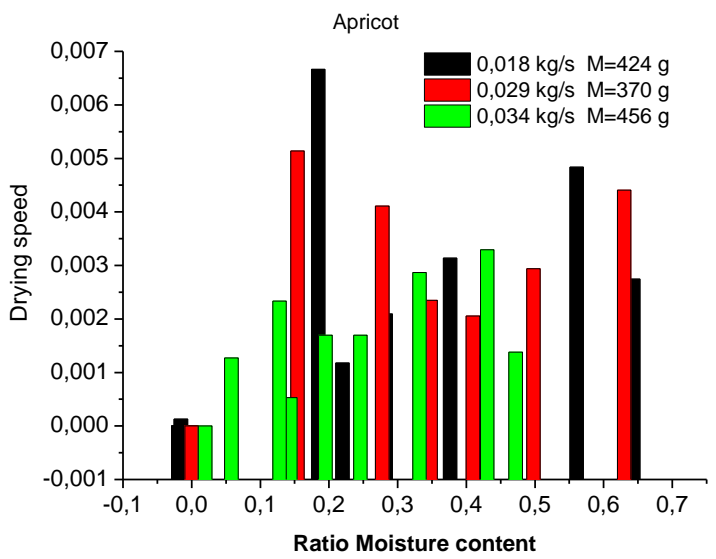

Figure 8. Drying speed versus moisture content of the Apricot

Figure 8 show the variation of drying speed as a function of moisture content of the Apricot according to three mass flow rates with a different total mass of the Apricot used. We can see the drying speed begin with increase evolution to arrive in the point of deviation when the drying speed attains the values equal to ratio 0.005 and 0.0065 according to ratio moisture content 0.15 and 0.2 , respectively the total mass of the Apricot 370 and $456 \mathrm{~g}$. We conclude that mass flow rate of the air comes less versus the drying speed come fast.

The global solar radiation it's begin with less power and increase to arrive a maximum value in median sun and then decrease to arrive a minimum value, see Fig.9. We can observe that the global solar radiation takes the maximum value with three days of the tests from 800 to $1050 \mathrm{~W} / \mathrm{m}^{2}$. This power used in the solar collector for heat air which gives the important temperature of drying chamber.

The figure 10 show, the evolution of relative humidity which goes to inlet solar collector, according to three days of the test, we can be seen the maximum variation is in the first 
days of the test and come minimum with approach in the second and last day.

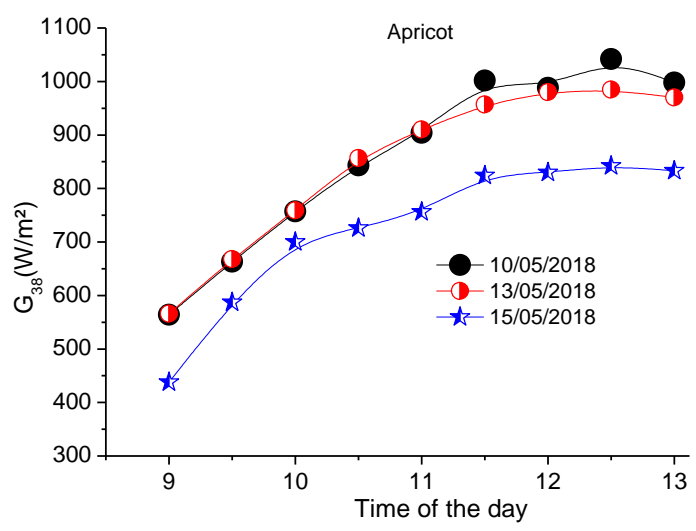

Figure 9. Global solar radiation according to three days, respectively

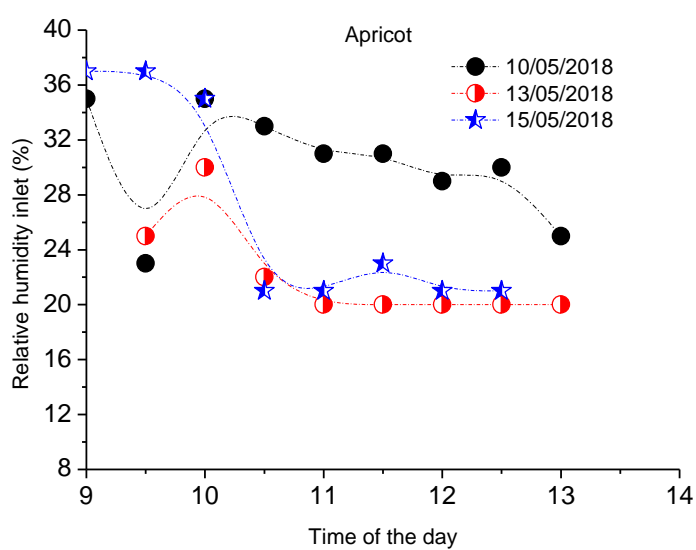

Figure 10. Relative humidity in the inlet solar collector

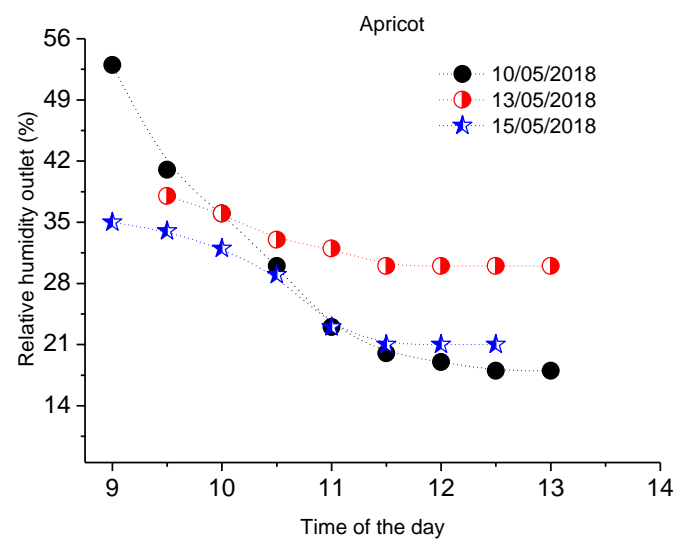

Figure 11. Relative humidity in the outlet drying chamber

The figure 11 show, the progression of relative humidity which goes to outlet drying chamber, according to three days of the test, we can be remarked that values come much of the inlet solar collector which means the product out much the wet content and that what I needed to come. In the first days the relative humidity is going with a maximum values which begin with it $53 \%$ and the median in the second day with $38.5 \%$, and a last variation in the last day with a minimum attain $35 \%$.

A during the heat air with solar collector which gives this temperature to drying chamber when the product put it inside on the support, under all this we create the source of distribution under the form of orifices in favor of homogenate the heat inside all chamber. In the figure 12, show the variation of temperature of the Apricot according to time of the day, we can see all the evolution curves begin with a less temperature and then take a more in the median sun time and for after that is stable with fixe temperature. When the mass flow rate take a much is associating that the product get a much the heat from air.

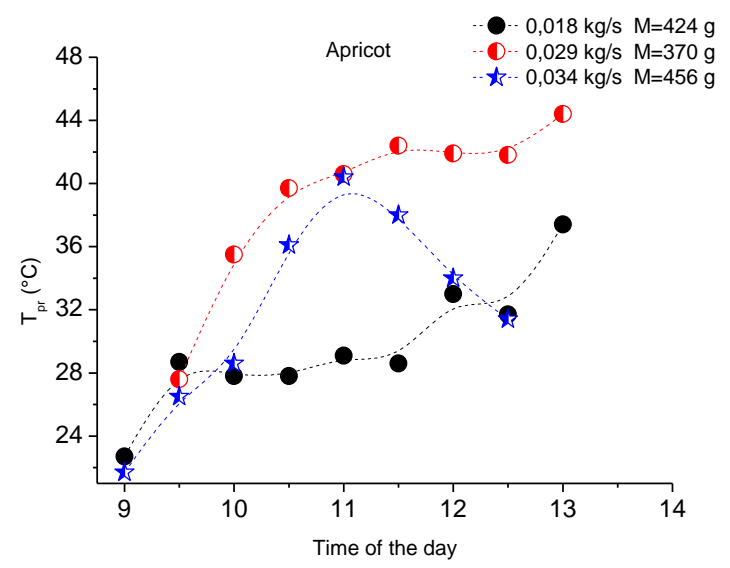

Figure 12. Temperature of the product of Apricot in the drying chamber

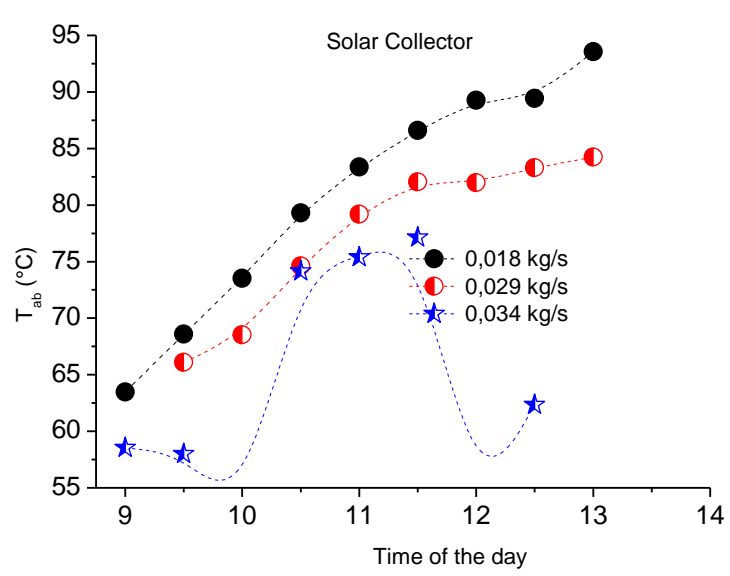

Figure 13. Temperature of the absorber plate of solar collector

In this study the heat air come from the absorber plate of a solar collector design see Figure 13, about this point we illustrate the curves of temperature an absorber plate for determinate the action with evacuated air in the streaming of collector to the drying chamber it's necessity for this part. When the temperature an absorber is high implicate that the temperature enter of the drying chamber come much it is important in this test see Figure 14. The evolutions come parallel with variation of global solar radiation effect see Figure 9.

The drying chamber receives the temperature from the solar collector which absorbed from sun. The figure 14, show the variation of temperature of drying chamber sensor situated in the centre of the chamber. We remark that the temperature started with low temperature and finish with high temperature according to environment weather outside the experimental setup. The evolution come in versus varying with mass flow rate when lower implicate higher temperature in against come correct. About the last days we can be seen that irregular variation cause the solar radiation is irregular. 




Figure 14. Temperature of the drying chamber

\section{CONCLUSIONS}

This work allowed us to study the effects of some parameters on drying and specify the most influential.

It is necessary to indicate that the results obtained and represented by the different curves according to the studied model, are built on real experiments.

For the capture surface, the increase of this factor makes it possible to increase the solar power captured. This leads to the elevation of the air temperature within the sensor allowing a short drying time. Thus, the drying air temperature, the flow rate, the mass of the product, and the solar radiation are important factors in increasing the efficiency of the dryer.

We are trying to test the apricot by it and the result talk about this design realized, it is the observation study.

\section{REFERENCES}

[1] Umayal Sundari AR, Neelamegam P, Subramanian CV. (2013). An experimental study and analysis on solar drying of bitter gourd using an evacuated tube air collector. Conference Papers in Energy, Thanjavur, Tamil Nadu, India.

[2] Khalifa AJN, Al-Dabagh AM, Al-Mehemdi WM. (2012). An experimental study of vegetable solar drying systems with and without auxiliary heat. ISRN Renewable Energy 2012, Article ID 789324, 8 pages. http://dx.doi.org/10.5402/2012/789324

[3] Esper A, Muhlbauer W. (1998). Solar drying -an effective means of food preservation. Renew Energy 15(1-4): $\quad 95-100 . \quad$ https://doi.org/10.1016/S09601481(98)00143-8

[4] Ahmad F, Kamaruzzaman S, Mohammad HY, Mohd HR, Mohamed G, Hussein AK. (2014). Performance analysis of solar drying system for red chili. Sol. Energy 99: $47-54$.

https://doi.org/10.1016/j.solener.2013.10.019

[5] Bahloul N, Boudhrioua N, Kouhila M, Kechaou B. (2009). Effect of convective solar drying on colour, total phenols and radical scavenging activity of olive leaves (Olea europaea L). Int. J. Food Sci. Technol. 44(12): 2561-2567. https://doi.org/10.1111/j.13652621.2009.02084.x

[6] Banout J, Havlik J, Kulik M, Kloucek P, Lojka B. (2010). Effect of solar drying on the composition of essential oil of sacha culantro (Eryngium foetidum L) grown in the peruvian amazon. J. Food Process. Eng. 33(1): $\quad 83-103 . \quad$ https://doi.org/10.1111/j.17454530.2008.00261.x

[7] Tadahmun AY, Hussian HA. (2016). Experimental investigation and evaluation of hybrid solar/termal dryer combined with supplementary recovery dryer. Sol. Energy 134: 284-293. https://doi.org/10.1016/j.solener.2016.05.011

[8] Leon MA, Kumar S. (2008). Design and performance evaluation of a solar assisted biomass drying system with thermal storage. Dry Technol. 26(7): 936-947. https://doi.org/10.1080/07373930802142812

[9] Abdullah K. (1997). Drying of vanilla pods using a greenhouse effect solar dryer. Dry Technol. 15(2): 685698. https://doi.org/10.1080/07373939708917254

[10] Bechoff A, Dufour D, Dhuique-Mayer C, Marouzé C, Reynes M, Westby A. (2009). Effect of hot air, solar and sun drying treatments on provitamin a retention in orange- fleshed sweet potato. J. Food Eng. 92(2), 164171. https://doi.org/10.1016/j.jfoodeng.2008.10.034

[11] Hii CL, Abdul Rahman R, Jinap S, Che Man YB. (2006). Quality of cocoa beans dried using a direct solar dryer at different loadings. J. Sci. Food Agri. 86(8): 1237-1243. https://doi.org/10.1002/jsfa.2475

[12] Fadhel MI, Sopian K, Daud WRW, Alghoul MA. (2010). Performance analysis of solar-assisted chemical heat-pump dryer. Sol. Energy 84(11): 1920-1928. https://doi.org/10.1016/j.solener.2010.07.001

[13] Li Y, Li HF, Dai YY, Gao SF, Wei L, Li ZL, Odinez IG Wang RZ. (2011). Experimental investigation on a solar assisted heat pump in-store drying system. Appl. Thermal Eng. 31(10): 1718-1724. https://doi.org/10.1016/j.applthermaleng.2011.02.014

[14] Jairaj KS, Singh SP, Srikant K. (2009). A review of solar dryers developed for grape drying. Sol. Energy 83(9): https://doi.org/10.1016/j.solener.2009.06.008

[15] Chabane F, Moummi N, Benramache S, Bensahal D, Belahssen O. (2013). Collector efficiency by single pass of solar air heaters with and without using fins. Engineering Journal 38(1): 44-53. https://doi.org/10.1016/j.icheatmasstransfer.2010.09.01 5

[16] Chabane F. (2014). Noureddine moummi, said benramache, heat transfer and energy analysis of a solar air collector with smooth plate. The European Physical Journal Applied Physics 66(1): 10901.

[17] Chabane F, Hatraf N, Moummi N. (2014). Experimental study of heat transfer coefficient with rectangular baffle fin of solar air heater. Frontiers in Energy 8(2): 160-172.

[18] Chabane F, Moummi N, Bensahal D, Brima A. (2014). Heat transfer coefficient and thermal losses of solar collector and Nusselt number correlation for rectangular solar air heater duct with longitudinal fins hold under the absorber plate. Applied Solar Energy 50(1): 19-26.

[19] Chabane F, Moummi N, Benramache S. (2014). Experimental study of heat transfer and thermal performance with longitudinal fins of solar air heater. Journal of Advanced Research 5(2): 183-192. https://doi.org/10.1016/j.jare.2013.03.001

[20] Chabane F, Moummi N, Brima A, Benramache S. (2013). Thermal efficiency analysis of a single-flow 
solar air heater with different mass flow rates in a smooth plate. Frontiers in Heat and Mass Transfer 4(1).

[21] Chabane F, Moummi N, Benramache S, Bensahal D, Belahssen O. (2013). Effect of artificial roughness on heat transfer in a solar air heater. Journal of Science and Engineering 1(2): 85-93.

[22] Chabane F, Moummi N, Benramache S. (2013). Experimental analysis on thermal performance of a solar air collector with longitudinal fins in a region of Biskra, Algeria. Journal of Power Technologies 93(1): 52-58.

[23] Chabane F, Moummi N, Benramache S, Lemmadi FZ. (2013). Thermal performance optimization of a flat plate solar air heater. International Journal of Energy \& Technology 5(8): 1-6.

[24] Chabane F, Moummi N, Benramache S. (2012). Experimental study on heat transfer for a solar air heater and contribution the fins to improve the thermal efficiency. International Journal of Advanced Renewable Energy Researches 1(9).

[25] Chabane F, Moummi N, Benramache S. (2012) Experimental performance of solar air heater with internal fins inferior an absorber plate: In the region of Biskra. International Journal of Energy \& Technology 33(4): 1-6.

[26] Chabane F, Moummi N, Benramache S. (2012). Effect of the tilt angle of natural convection in a solar collector with internal longitudinal fins. Journal of Science and Engineering Investigations 1: 13-17.

\section{NOMENCLATURE}

$m$

G

$V_{\text {wind }}$

$T_{a m b}$

$T_{e, \text { cham }}$

$T_{s, \text { cham }}$

$T_{p r}$

$T_{\text {cham }}$

$\Delta T_{\text {Chambre }}$

$M_{t}$

$M_{a n}$

$M_{w}$

$X_{r}$

$X$

\section{Subscripts}

$\begin{array}{ll}\text { wind } & \text { wind } \\ \text { amb } & \text { Ambient } \\ \text { e } & \text { inlet } \\ \mathrm{s} & \text { outlet } \\ \text { cham } & \text { Chamber or room } \\ \mathrm{t} & \text { Total } \\ \text { an } & \text { anhydrous } \\ \text { w } & \text { water }\end{array}$

dry anhydrous $g$

Water mass $g$

water
Mass flow rate $\mathrm{kg} . \mathrm{s}^{-1}$

Global solar radiation W.m-2

Velocity wind $\mathrm{m} . \mathrm{s}^{-1}$

Ambient temperature ${ }^{\circ} \mathrm{C}$

Inlet temperature of drying room ${ }^{\circ} \mathrm{C}$

Outlet temperature of drying room ${ }^{\circ} \mathrm{C}$

Temperature of product ${ }^{\circ} \mathrm{C}$

Temperature of room ${ }^{\circ} \mathrm{C}$

Different temperature ${ }^{\circ} \mathrm{C}$

Total mass of procut $\mathrm{g}$

Moisture-based water content \%

Absolute humidity kgav / kgas 